\title{
The Relationship between the Students' Socialization and Sense of Belonging Who Attended University's Spring Festivals
}

\author{
Zekiye Basaran ${ }^{1, *}$, Ayşe Demir ${ }^{2}$ \\ ${ }^{1}$ Department of Sport Management, Faculty of Sport Science, Kocaeli University, Turkey \\ ${ }^{2}$ Department of Sport Management, School of Applied Sciences, Istanbul Aydin University, Turkey
}

Copyright $\bigcirc 2017$ by authors, all rights reserved. Authors agree that this article remains permanently open access under the terms of the Creative Commons Attribution License 4.0 International License

\begin{abstract}
The aim of this study is to investigate the effect of spring festivals on university students' socialization and sense of belonging. According to this aim, this study's sample was 983 volunteer students including 460 women and 523 men who were studying at İstanbul Yıldız Technical University and İstanbul Aydın University. The data collection tools $(p<0,05)$ consisted of a short collating the students' gender, age, class, university department, and other information concerning their university; the 'General Belonging' scale reformed by Malone et al. (2012) and adapted into Turkish by Duru (2015); and the 'Socializing' scale reformed by Şahan (2008). According to the results of this study, it was discovered that spring festivals have an effect on students' socialization and sense of belonging. Statistically significant differences were found with regard to the universities. Also, differences between belonging and socialization, as well as a significant correlation between belonging and socialization were found. In the light of these findings, it can be said that, spring festivals have a positive effect on students' socialization and improve their sense of belonging; therefore, spring festivals should be organized in a sustainable way at every university.
\end{abstract}

Keywords Spring Festivals, University, Belonging, Socialization

\section{Introduction}

Belonging is an important concept in people's lives. It is a connection which is forged between people and the society, and through this connection, people can live together with other people from their society (Alptekin, 2011). Belonging has a sensual element. If belonging is identified via this sensual element; it is a feeling concerning a person gaining admission to society and approved by society based on this admission (Kusat, 2003).

It can be said that, belonging is a sense which is developed by people, against a society and which is important for people's lives. However, belonging is important for student's lives because it is accepted that, students will enhance their sense of belonging to their educational institution. It is known that there are some results regarding enhancing this sense of belonging to educational institutions. Before explaining these results, it would be useful to answer the question of what is this sense of belonging to a school is. A feeling such as that of belonging to a school is connected with, how a student is approved by the people at that school - the other students, the instructors, other personnel - and how often the student integrates with the school's activities and procedures (Goodenow and Grady, 1993). Feeling this sense of belonging or, in other words, developing a sense of belonging to a school is an important factor during one's education. Being approved by others at school and being able to attend the processes and activities there will help students develop positive feelings about their school such as happiness, pride, and complacency; but, on the contrary, not being approved by the others at school and not being able to attend the processes and activities there has the effect of developing negative feelings such as sadness, loneliness, and dissatisfaction (Osterman, 2000).

During a student's education, if he/she enhances his/her sense of belonging to his/her school, it can be seen that, this student is more concerned about the school's activities, attending these activities, appreciating the school, and developing positive feelings for the school, and, as a result, being more disposed to education (Karatzias et. al, 2001). Therefore, it can be said that students who have a greater sense of belonging are more successful in their education. According to Osterman (2000), these students perform well and produce better results than others (Osterman, 2000). Accordingly, having a keen sense of belonging to their 
school is about students' happiness, self-satisfaction, and complacency, as well as about their academic achievements. If their sense of belonging improves this situation, it will help with their socialization processes and social status, as well as loving their school and not feeling estranged.

Another concept included in this research is socialization. Socialization is a concept of people and society such as a sense of belonging. In general, socialization is about a person's communication with other people in society, and learning about the processes in that society and espousing these processes (Atalay, 2012).

It is known that, people are social creatures. Therefore, it can be said that socialization is a basic need for other people. In general, socialization is about a person's character, talent, and ability to communicate with other people in society.

Socialization is accepted as a process and is important in the formation of personality. Socialization processes have some norms which are shaped by societies' culture. These norms are also important for people's socialization processes; they designate the needs for socialization (Ertürk, 2010). Moreover, it should be remembered that, socialization is shaped by people's experiences and specifications.

Socialization processes do not always result in individual efforts being efficient. Sometimes these efforts should be supported by activities which do have an effect on socialization. Through these activities, people can easily socialize and be integrated into society. If this concept is approached according to the research population - the university students - at universities activities which help students to socialize are organized. These activities are called recreational activities. According to Bucher and Bucher (1974), these activities are good for university students' individual egos; they help students interact with each other, and as a result help them to socialize. These activities also help university students not to become introverted, but rather happy, efficient, and sociable. As a result, it can be said that as a recreational activity, spring festivals also have a positive effect on students' socialization.

\section{Method}

\section{Research Method}

This research was conducted using a quantitative research method. Quantitative research methods evaluate and explain human behavior by using numerical data (Akman, 2014).This research's design a descriptive survey model. It was conducted on students from two universities in Turkey. Before starting this research, the necessary permission for conducting research at the universities was granted. The research was conducted between 1 to 10 June, 2017, and a face-to-face interview method was used.

\section{The Aim of the Research}

The aim of this study is to investigate the effect of spring festivals on university students' socialization and sense of belonging.

\section{Problem Statement}

The main clause of this research is; people who have a sense of belonging are also social people, and spring festivals have a positive effect on improving this sense of belonging and socialization. The sub- problem statements of this research are;

- Spring festivals contribute to university students' sense of belonging.

- Spring festivals improve university students' level of socialization.

- There is a relationship between a sense of belonging and socialization.

\section{Population and Sample}

This research's population was the universities which organized spring festivals (State University) Istanbul Technic University and (Foundation University) Istanbul Aydın University. The sample of this study was the 460 women and 523 men as total of 983 students that attend spring festivals and volunteer to apply our research.

\section{Data Collection Tool}

There were three data collection tools in this study. These were: (i) A personal information form; (ii) the "General Belonging Scale" developed by Malone, Pillow, and Osman (2012), and adapted into Turkish by Duru (2015); and (iii) the "Socializing by Sports Scale" developed by Şahan (2008).

\section{Personal Information Form}

This short form collected information about the students, their gender, age, class, department, and university.

\section{General Belonging Scale}

The "General Belonging Scale" developed by Malone, Pillow, and Osman (2012), and adapted into Turkish by Duru (2015), was used to scale the university students' general sense of belonging. This scale has two basic dimensions: (i) Acceptance / inclusion and (ii) lack of rejection and exclusion. The points concerning the second dimension of the scale - lack of rejection and exclusion can be used and revised. If the points taken from the scale increased, it showed that the sense of belonging was improving. A reliability analysis was conducted on the scale according to the participants' answer and the Cronbach's Alpha was calculated for the scale. The Cronbach's Alpha of the scale, which contained 12 questions was 0,881 , and it can be said that the scale is reliable. 


\section{Socialization Scale}

To measure the participants' level of socialization, the "Socializing by Sports Scale" developed by Şahan (2008) was used. This scale was developed by Şahan (2008) by using the "Hacettepe Personality Inventory," the, "Sociotomy - Autonomy Scale," the, "Social Comparison Scale," a "Social Recognition Questionnaire," and a, "Personal Information Form," and a pilot scheme was conducted before using this scale (Şahan, 2008). During this research, the "sport" premise on this scale was used as an "activity." A reliability analysis was conducted to the scale according to the participants' answers and the Cronbach's Alpha was calculated for the scale. The Cronbach's Alpha of the scale, which contained 35 questions was 0,903 , and it can be said that the scale is reliable.

\section{Techniques of Analysis of Data}

The data obtained from the scales were evaluated by the SPSS 18 package program. The frequency and percentage distribution of the demographic findings were calculated. A Cronbach's Alpha was used to measure the reliability of the scales; an independent t-test was used to find out if there were any differences in the data according to the universities; an ANOVA test used to find out if there were any differences between the data according to the demographic findings; , and a Pearson Correlation test was conducted to find out if there was a relationship between belonging and socialization. The significance level was approved as $\mathrm{p}<0,05$.

\section{Findings}

The demographic characteristics of the university students who participated in this research are shown in Table 1.

According to Table 1, 523 (53\%) of the students are male and $460(46,8 \%)$ of the students are female; 531 (54\%)- of them are students at Yildiz Technical University (YTÜ) and, $452(46 \%)$ are students at İstanbul Aydın University (İAÜ);, $535(54,4 \%)$ are between the ages of 18 and $21,-409(41,6 \%)$ are between the ages of 22 and -25 , and $39(11,2 \%)$ of the students are over 25 years old. 249 $(25,3 \%)$ of the students are continuing Grade I, $332(33,8 \%)$ of them are continuing Grade II, $192(19,5 \%)$ are continuing Grade III, $184(18,7 \%)$ are continuing Grade IV, $23(2,3 \%)$ are continuing prep class, and $3(3 \%$, ) of them are post-graduate students.

Table 1. Demographic characteristics

\begin{tabular}{cccc}
\hline & & $\mathrm{f}$ & $\%$ \\
\hline \multirow{3}{*}{ Gender } & Female & 523 & 53,2 \\
& Male & 460 & 46,8 \\
University & Total & 983 & 100,0 \\
& Yildiz Technical University & 531 & 54,0 \\
& Istanbul Aydin University & 452 & 46,0 \\
Age & Total & 983 & 100,0 \\
& 18-21 Years & 535 & 54,4 \\
& 22-25 Years & 409 & 41,6 \\
& 26-29 Years & 31 & 3,2 \\
& Over 30 Years & 8 &, 8 \\
Class & Total & 983 & 100,0 \\
& Grade I & 249 & 25,3 \\
& Grade II & 332 & 33,8 \\
& Grade III & 192 & 19,5 \\
& Grade IV & 184 & 18,7 \\
& Prep Class & 23 & 2,3 \\
& Post Graduate & 3 & 3 \\
& Total & 983 & 100,0 \\
\hline
\end{tabular}

An independent t-test was conducted to compare the socialization and sense of belonging scale points of the participants according to their universities. The findings of this test are shown in Table 2.

According to Table 2, there is a large significant difference between the socializing scale points of the participants at Yıldız Technical University and İstanbul Aydın University $(, 000)$. The scale points of the Yıldız Technical university students are $132,5398-22,55470$. If the sense of belonging scale points of the students is evaluated according to their university, there is a positive but small significant relationship. The scale points of the Yıldız Technical University students are 66,1450 13,99500 and the scale points of the İstanbul Aydin University students are 67,9313-.14,33356. The differences that occurred for both socialization and belonging were because of the Istanbul Aydın University' students.

Table 2. Comparison of the socialization and sense of belonging scale points according to universities (independent t-test)

\begin{tabular}{|c|c|c|c|c|c|c|}
\hline & University & $\mathrm{N}$ & Mean & Standard Deviation & $\mathrm{t}$ & $\mathrm{p}$ \\
\hline \multirow[t]{3}{*}{ Socializing } & Yıldız Technical & 531 & 123,4068 & 17,32422 & $-7,171$ & 000 \\
\hline & Istanbul Aydın University & 452 & 132,5398 & 22,55470 & & \\
\hline & Total & 983 & & & & \\
\hline \multirow[t]{3}{*}{ Belonging } & Yıldız Technical & 531 & 66,1450 & 13,99500 & $-1,971$ &, 049 \\
\hline & Istanbul Aydın University & 451 & 67,9313 & 14,33356 & & \\
\hline & Total & 983 & & & & \\
\hline
\end{tabular}


An independent t-test was conducted to compare the answers of the participants that were given to the belonging scale according to their universities. The findings of this test are shown in Table 3.

Table 3. Comparison of the answers of the belonging scale according to universities (independent t-test)

\begin{tabular}{|c|c|c|c|c|c|c|}
\hline Question & University & $\mathrm{N}$ & Mean & $\begin{array}{c}\text { Standard } \\
\text { Deviation }\end{array}$ & $\mathrm{t}$ & $\mathrm{p}$ \\
\hline \multirow{2}{*}{1} & Yıldız Technical & 531 & 5,1262 & 1,66004 & \multirow{2}{*}{$-3,632$} & \multirow{2}{*}{, 000} \\
\hline & Istanbul Aydın & 451 & 5,5255 & 1,78167 & & \\
\hline \multirow{2}{*}{2} & Yıldız Technical & 531 & 5,6008 & 1,51431 & \multirow{2}{*}{,- 044} & \multirow{2}{*}{,965 } \\
\hline & Istanbul Aydin & 451 & 5,6053 & 1,75230 & & \\
\hline \multirow{2}{*}{3} & Y1ldız Technical & 531 & 5,4896 & 1,54107 & \multirow{2}{*}{$-3,012$} & \multirow{2}{*}{, 003} \\
\hline & Istanbul Aydın & 451 & 5,7960 & 1,64197 & & \\
\hline \multirow{2}{*}{4} & Yıldız Technical & 531 & 5,1186 & 1,79071 & \multirow{2}{*}{$-4,394$} & \multirow{2}{*}{, 000} \\
\hline & Istanbul Aydın & 451 & 5,6053 & 1,65445 & & \\
\hline \multirow{2}{*}{5} & Yıldız Technical & 531 & 5,3202 & 1,77911 & \multirow{2}{*}{$-4,044$} & \multirow{2}{*}{, 000} \\
\hline & Istanbul Aydın & 451 & 5,7672 & 1,66170 & & \\
\hline \multirow{2}{*}{6} & Yıldız Technical & 531 & 5,4746 & 1,49994 & \multirow{2}{*}{$-2,435$} & \multirow{2}{*}{, 015} \\
\hline & Istanbul Aydın & 451 & 5,7206 & 1,66453 & & \\
\hline \multirow{2}{*}{7} & Yıldız Technical & 531 & 5,6591 & 1,78849 & \multirow{2}{*}{1,565} & \multirow{2}{*}{,118 } \\
\hline & Istanbul Aydın & 451 & 5,4590 & 2,21810 & & \\
\hline \multirow{2}{*}{8} & Y1ldız Technical & 531 & 5,8908 & 1,72204 & \multirow{2}{*}{,402 } & \multirow{2}{*}{,688 } \\
\hline & Istanbul Aydın & 451 & 5,8426 & 2,03951 & & \\
\hline \multirow{2}{*}{9} & Yıldız Technical & 531 & 5,7232 & 1,69478 & \multirow{2}{*}{,- 772} & \multirow{2}{*}{440} \\
\hline & Istanbul Aydın & 451 & 5,8137 & 1,98010 & & \\
\hline \multirow{2}{*}{10} & Yıldız Technical & 531 & 5,4030 & 1,80657 & \multirow{2}{*}{,- 442} & \multirow{2}{*}{,659 } \\
\hline & Istanbul Aydın & 451 & 5,4590 & 2,16333 & & \\
\hline \multirow{2}{*}{11} & Yıldız Technical & 531 & 5,6460 & 1,76306 & \multirow{2}{*}{,- 120} & \multirow{2}{*}{,904 } \\
\hline & Istanbul Aydın & 451 & 5,6608 & 2,09077 & & \\
\hline 12 & Y1ldız Technical & 531 & 5,6930 & 1,70955 &, 140 & ,889 \\
\hline
\end{tabular}

There is a large difference $(\mathrm{p}<0,05)$ according to the answers given to the question "I feel that I am really with people when I am together with them" (,000). The points of the YTÜ students are 5,1262 $\pm 1,66004$ and the points of the IAU students are 5,5255 $\pm 1,78167 \mathrm{dir}$. There is a significant difference between the answers given to the question "I feel that I am accepted by others" (,003). The points of students' of YTÜ is 5,4896 $\pm 1,54107$ while the points of the students of İAÜ are $5,7960 \pm 1,64197$ 'dir. The answers given to the clause "I have the sense of belonging" is significantly different $(0,000)$. The points of the YTÜ students' are 5,1186 $\pm 1,79071$ while the points of the İAÜ students are $5,6053 \pm 1,65445$ 'dir. The answers given to the question "I think that I am equal to others in relationships and sharing" are significantly different $(0,000)$. The points of the YTÜ students' are 5,3202 $\pm 1,77911$, while the points of the İAÜ students are 5,7672 $\pm 1,66170$. The answers given to the question "I feel that I have a connection with the people around me" are significantly different $(0,015)$. The points of the YTÜ students' are 5,4746 $\pm 1,49994$, while the points of the İAÜ students are $5,7206 \pm 1,66453$ 'dir. The source of the differences between all of these questions is the İAÜ students.

An independent $t$-test was conducted to compare the answers of the participants that were given to the socialization scale according to their universities. The findings of this test are shown in Table 4.

Table 4. Comparison the answers of the socialization scale according to universities (independent t-test)

\begin{tabular}{|c|c|c|c|c|c|c|}
\hline Question & University & $\mathrm{N}$ & Mean & Standard Deviation & $\mathrm{t}$ & $\mathrm{p}$ \\
\hline \multirow[t]{2}{*}{1} & Yıldız Technical & 531 & 4,09 & 1,035 & $-2,451$ & 0,14 \\
\hline & Istanbul Aydın & 452 & 4,26 & 1,097 & $-2,440$ & \\
\hline \multirow[t]{2}{*}{2} & Yıldız Technical & 531 & 3,43 & 1,114 & $-3,239$ & 0,001 \\
\hline & Istanbul Aydın & 452 & 3,67 & 1,255 & $-3,208$ & \\
\hline \multirow[t]{2}{*}{3} & Yıldız Technical & 531 & 3,29 & 1,178 & $-1,907$ & 0,61 \\
\hline & Istanbul Aydın & 452 & 3,45 & 1,433 & $-1,877$ & \\
\hline \multirow[t]{2}{*}{4} & Yıldız Technical & 531 & 3,81 & 1,171 & $-1,372$ & 0,176 \\
\hline & Istanbul Aydın & 452 & 3,92 & 1,371 & $-1,355$ & \\
\hline \multirow[t]{2}{*}{5} & Yildız Technical & 531 & 3,92 & 1,206 & $-1,702$ & 0,89 \\
\hline & Istanbul Aydın & 452 & 4,06 & 1,309 & $-1,691$ & \\
\hline \multirow[t]{2}{*}{6} & Yıldız Technical & 531 & 3,08 & 1,244 &,- 710 & 0,485 \\
\hline & Istanbul Aydın & 452 & 3,14 & 1,516 &,- 699 & \\
\hline \multirow[t]{2}{*}{7} & Yıldız Technical & 531 & 3,32 & 1,138 & $-4,482$ & 0,000 \\
\hline & Istanbul Aydın & 452 & 3,66 & 1,275 & $-4,442$ & \\
\hline \multirow[t]{2}{*}{8} & Yıldız Technical & 531 & 2,71 & 1,258 & $-4,623$ & 0,000 \\
\hline & Istanbul Aydın & 452 & 3,11 & 1,485 & $-4,562$ & \\
\hline \multirow[t]{2}{*}{9} & Yıldız Technical & 531 & 2,10 & 1,173 & $-1,162$ & 0,253 \\
\hline & Istanbul Aydın & 452 & 2,19 & 1,437 & $-1,144$ & \\
\hline
\end{tabular}




\begin{tabular}{|c|c|c|c|c|c|c|}
\hline \multirow{2}{*}{10} & Yıldız Technical & 531 & 3,00 & 1,225 &,- 730 & 0,471 \\
\hline & Istanbul Aydın & 452 & 3,06 & 1,449 &,- 720 & \\
\hline \multirow[t]{2}{*}{11} & Yıldız Technical & 531 & 3,14 & 1,172 & $-3,679$ & 0,000 \\
\hline & Istanbul Aydın & 452 & 3,42 & 1,221 & $-3,667$ & \\
\hline \multirow[t]{2}{*}{12} & Yıldız Technical & 531 & 3,47 & 1,167 & $-4,392$ & 0,000 \\
\hline & Istanbul Aydın & 452 & 3,80 & 1,185 & $-4,386$ & \\
\hline \multirow[t]{2}{*}{13} & Yıldız Technical & 531 & 3,88 & 1,100 & $-2,960$ & 0,003 \\
\hline & Istanbul Aydın & 452 & 4,10 & 1,185 & $-2,942$ & \\
\hline \multirow[t]{2}{*}{14} & Yıldız Technical & 531 & 3,91 & 1,105 & $-1,960$ & 0,52 \\
\hline & Istanbul Aydın & 452 & 4,06 & 1,224 & $-1,944$ & \\
\hline \multirow[t]{2}{*}{15} & Yıldız Technical & 531 & 3,56 & 1,246 & $-4,329$ & 0,000 \\
\hline & Istanbul Aydın & 452 & 3,90 & 1,248 & $-4,329$ & \\
\hline \multirow[t]{2}{*}{16} & Yıldız Technical & 531 & 3,23 & 1,268 & $-6,779$ & 0,000 \\
\hline & Istanbul Aydın & 452 & 3,79 & 1,319 & $-6,757$ & \\
\hline \multirow[t]{2}{*}{17} & Yıldız Technical & 531 & 3,93 & 1,076 & $-4,757$ & 0,000 \\
\hline & Istanbul Aydın & 452 & 4,27 & 1,116 & $-4,743$ & \\
\hline \multirow[t]{2}{*}{18} & Yıldız Technical & 531 & 3,44 & 1,130 & $-5,520$ & 0,000 \\
\hline & Istanbul Aydın & 452 & 3,85 & 1,211 & $-5,489$ & \\
\hline \multirow[t]{2}{*}{19} & Yıldız Technical & 531 & 3,92 & 1,083 & $-4,094$ & 0,000 \\
\hline & Istanbul Aydın & 452 & 4,20 & 1,084 & $-4,094$ & \\
\hline \multirow[t]{2}{*}{20} & Yıldız Technical & 531 & 3,59 & 1,105 & $-4,891$ & 0,000 \\
\hline & Istanbul Aydın & 452 & 3,94 & 1,195 & $-4,860$ & \\
\hline \multirow[t]{2}{*}{21} & Yıldız Technical & 531 & 3,84 & 1,134 & $-4,203$ & 0,000 \\
\hline & Istanbul Aydın & 452 & 4,15 & 1,183 & $-4,188$ & \\
\hline \multirow[t]{2}{*}{22} & Yıldız Technical & 531 & 2,52 & 1,329 & $-2,329$ & 0,022 \\
\hline & Istanbul Aydın & 452 & 2,73 & 1,536 & $-2,302$ & \\
\hline \multirow[t]{2}{*}{23} & Yıldız Technical & 531 & 3,16 & 1,209 & $-2,157$ & 0,033 \\
\hline & Istanbul Aydın & 452 & 3,34 & 1,328 & $-2,141$ & \\
\hline \multirow[t]{2}{*}{24} & Yıldız Technical & 531 & 4,02 & 1,042 & $-2,238$ & 0,027 \\
\hline & Istanbul Aydın & 452 & 4,17 & 1,141 & $-2,222$ & \\
\hline \multirow[t]{2}{*}{25} & Yıldız Technical & 531 & 3,69 & 1,092 & $-5,420$ & 0,000 \\
\hline & Istanbul Aydın & 452 & 4,07 & 1,107 & $-5,414$ & \\
\hline \multirow[t]{2}{*}{26} & Yıldız Technical & 531 & 3,68 & 1,096 & $-5,475$ & 0,000 \\
\hline & Istanbul Aydın & 452 & 4,07 & 1,175 & $-5,444$ & \\
\hline \multirow[t]{2}{*}{27} & Yıldız Technical & 531 & 3,86 & 1,042 & $-4,755$ & 0,000 \\
\hline & Istanbul Aydın & 452 & 4,18 & 1,110 & $-4,731$ & \\
\hline \multirow[t]{2}{*}{28} & Yıldız Technical & 531 & 3,93 & 1,081 & $-4,000$ & 0,000 \\
\hline & Istanbul Aydın & 452 & 4,21 & 1,105 & $-3,993$ & \\
\hline \multirow[t]{2}{*}{29} & Yıldız Technical & 531 & 3,90 & 1,061 & $-4,296$ & 0,000 \\
\hline & Istanbul Aydın & 452 & 4,19 & 1,046 & $-4,301$ & \\
\hline 30 & Yıldız Technical & 531 & 3,72 & 1,260 & $-3,291$ & 0,001 \\
\hline & Istanbul Aydın & 452 & 3,98 & 1,250 & $-3,293$ & \\
\hline 31 & Yıldız Technical & 531 & 3,71 & 1,111 & $-3,492$ & 0,001 \\
\hline & Istanbul Aydın & 452 & 3,97 & 1,252 & $-3,458$ & \\
\hline 32 & Yıldız Technical & 531 & 4,05 & 1,050 & $-3,148$ & 0,002 \\
\hline & Istanbul Aydın & 452 & 4,26 & 1,080 & $-3,141$ & \\
\hline 33 & Yıldız Technical & 531 & 3,13 & 1,222 & $-3,149$ & 0,002 \\
\hline & Istanbul Aydın & 452 & 3,39 & 1,405 & $-3,114$ & \\
\hline 34 & Yıldız Technical & 531 & 3,77 & 1,084 & $-2,249$ & 0,027 \\
\hline & Istanbul Aydın & 452 & 3,94 & 1,277 & $-2,220$ & \\
\hline 35 & Yıldız Technical & 531 & 3,63 & 1,117 & $-4,978$ & 0,000 \\
\hline & Istanbul Aydın & 452 & 4,00 & 1,222 & $-4,942$ & \\
\hline
\end{tabular}

There is a large significant difference between the answers of the students according to their universities $(\mathrm{p}<0,05)$ to the scale questions " $m y$ interests and talent are the determiners for choosing an activity that interests me" $(0,014)$, "I think I am more successful at individual activities,", "people can recognize me easily during activities,", "one of the most important pleasures for me is to conduct activities with people I don't know,", "I become the group leader during team activities,", "I am good at conducting the teams during team activities,", "People who take part in activities have peace of mind,", "I contribute to organizing activities", "I love attending all types of activities,", "I always tell the truth and stand up for myself even though others reject me,", I prefer team activities,", "Activities provide social integration between societies,", "I express myself more freely during activities,", "Activities provide social integration,", "During these activities (i.e. sports) anti-social behaviors such as swearing and unsporting behavior can be tolerated,", "Instead of being part of a group, I prefer to be an individual who has unique values,", "Activities contribute to communication between people,", "I can adapt myself easily to every activity,", "I can communicate with others easily during activities,", "Activities play an important role in raising useful people for society,", "Activities help discover individual talents,", "Activities contribute to positive emotions toward other people,", "It is hard for me to be away from the people I love,", 
"I like spending my spare time with other people,", "I like to do activities with my friends,", "My family, my school, and my external environment are the determiners for choosing an activity,", "I prefer to help others instead of others helping me,", "I prefer to be part of activities involving other people instead of individual activities.". The source of the differences between all of these questions is the İAÜ students.

The results of the independent $t$-test conducted to find the answers to the belonging scale according to gender are shown in Table 5.

Table 5. Differences between the belonging scale and gender (independent t-test)

\begin{tabular}{ccccccc}
\hline & Gender & $\mathrm{N}$ & $\mathrm{Mean}$ & Standard Deviation & $\mathrm{t}$ & $\mathrm{p}$ \\
\hline General & Male & 523 & 67,8317 & 13,64304 & & \\
Belonging & Female & 459 & 65,9782 & 14,70494 & 2,048 &, 041 \\
\hline
\end{tabular}

According to Table 5, there is a significant difference between belonging and gender $(0,041)$. The male points are $67,8317 \pm 13,64304$ and the female points are $65,9782 \pm 14,70494$. The source of this difference' is males.

During this research we tried to find out whether there is a relationship between belonging and socialization. The statistical findings regarding this relation are shown in Table 6 .

Table 6. Relationship between belonging and socialization (correlation)

\begin{tabular}{cccc}
\hline & & Belonging & Socialization \\
\hline \multirow{3}{*}{ Belonging } & Pearson Correlation & 1 &, $360^{* *}$ \\
& Sig. (2-tailed) & &, 000 \\
& N & 982 & 982 \\
Socialization & Pearson Correlation &, $360^{* *}$ & 1 \\
& Sig. (2-tailed) &, 000 & \\
& $\mathrm{~N}$ & 982 & 983 \\
\hline
\end{tabular}

**. Correlation is significant at the $\mathbf{0 . 0 1}$ level

According to Table 6, there is a significant difference between the participants' belonging points and the socialization points at a level of $0,01(0,000)$.

\section{Results, Conclusion, and Recommendations}

The aim of this study is to find out the effects of spring festivals on the sense of belonging and socialization perceptions of university students. $523(53 \%)$ are male and the $460(46,8 \%)$ are female; $531(54 \%)$-of them are students at Yıldız Technical University (YTÜ) and, 452 (46\%) are students at İstanbul Aydın University (İAÜ); $535(54,4 \%)$ are between the ages of 18 and $21,409(41,6 \%)$ are between the age of 22 and -25 and $39(11,2 \%)$ of the students are over 25 years old. $-249(25,3 \%)$ of the students are continuing Grade I, $332(33,8 \%)$ are continuing Grade II, $192(19,5 \%)$ of them are continuing Grade III, 184 $(18,7 \%)$ of them are continuing Grade IV, $23(2,3 \%)$ are continuing prep class, and $3(3 \%)$ are post-graduate students (Table 1).
When the socialization and belonging scale points are compared, it can be observed that there is a large significant difference between the Yıldız Technical University students and the İstanbul Aydın University students. The points of the Ylldiz Technical University' students are 123,4068 $\pm 17,32422$, while those of the İstanbul Aydin University' students are $132,5398 \pm 22,55470$ 'dır. There is a small significant difference between the belonging points of the students $(0,049)$. The points of the Yildı Technical University' students are 66,1450 $\pm 13,99500$, while those of the İstanbul Aydın University' students are 67,9313 $\pm 14,33356$. Both of these differences are found in the İstanbul Aydın University students (Table 2).

According to the research conducted by Filiz (2010), Eskişehir Osmangazi University and Anadolu University students were used as a sample, and an evaluation was carried out to find out their socialization. In this research, the "Socializing" scale developed by Şahan (2008) was used. A questionnaire was given to 248 students. The main result of this study was that, sports have a positive effect on university students' socialization and integration. The same as our research, Filiz (2010) conducted her research at two universities. The main difference between Filiz's (2010) research and this research is that, both the universities used in Filiz's (2010) research were government universities. The main difference according to the findings of this research is that, - the Eskişehir Osmangazi University' students gave more importance to choosing their activities according to their interests and talents than the Eskişehir Anadolu University students. Another difference between the findings of the universities is that the, Osmangazi University students like conducting activities together more than the students at Anadolu University.

There is a large difference $(p<0,05)$ according to the answers to the question "I feel that I am really with people when I am together with them" $(, 000)$. The points of the YTÜ students are 5,1262 $\pm 1,66004$, and the points of the IAU students are 5,5255 $\pm 1,78167$. There is a significant difference between the answers to the question "I feel that I am accepted by others" $(, 003)$. The points of students' of YTÜ is 5,4896 $\pm 1,54107$ while the points of the students 


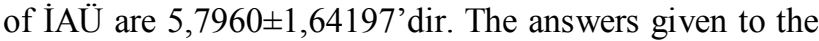
clause "I have the sense of belonging" is significantly different $(0,000)$. The points of students' of YTÜ is $5,1186 \pm 1,79071$ while the points of the students of İAÜ are $5,6053 \pm 1,65445^{\prime}$ 'dir. The answers given to the question "I think that I am equal to others in relationships and sharing" are significantly different $(0,000)$. The points of the YTÜ students' are 5,3202 $\pm 1,77911$, while the points of the İAÜ students are 5,7672 $\pm 1,66170$. The answers given to the question "I feel that I have a connection with the people around me" are significantly different $(0,015)$. The points of the YTÜ students' are $5,4746 \pm 1,49994$, while the points of the İAÜ students are $5,7206 \pm 1,66453$. The source of the differences between all of these questions is the İAÜ students (Table 3).

The research about the "level of belonging of students" has been investigated. Some research conducted by Öz (2014) was about the level of corporate belonging. Öz (2014) tried to evaluate the level of corporate belonging of students at a Faculty of Theology. According to this subject, a questionnaire was given to students at the Abant İzzet Baysal University Faculty of Theology. It was discovered that the level of corporate belonging of the students at the Faculty of Theology was high.

There was a significant difference between belonging and gender $(0,041)$. The male points are $67,8317 \pm 13,64304$ and the female points are $65,9782 \pm 14,70494$. This source of this difference's is the males (Table 5).

Some research conducted by Sar1 (2013) discovered, that there is no significant difference between the sense of belonging points of males and females, but there is a small difference in that female students have a slightly greater sense of belonging than male students (Sar1, 2013).

According to the research results, there is a small significant (,360) relationship between the students' belonging points and their socialization points $(0,000)$. This relationship shows us that, students who have a strong sense of belonging are also social students (Table 6).

As a result, it can be said that, this research shows that, spring festivals improve students' socialization and contribute to their sense of belonging. Therefore, it can be said that, in order to improve students' sense of belonging and to contribute to their socialization, spring festivals should be organized at every university. The most important point is that, these activities - spring festivals should be sustainable. It has been suggested that, spring festivals should be organized by every university to improve university students' corporate sense of belonging, thus preventing students from being absent, and improving their efficiency.

\section{REFERENCES}

[1] Akman, G.N. (2014). Nicel ve nitel araştırma yöntemleri, T.C. Afyon Kocatepe Üniversitesi Yönetim ve Organizasyon Bölümü, Bilimsel Araştırma Yöntemleri Dersi.

[2] Alptekin, D. (2011). Toplumsal aidiyet ve gençlik: üniversite gençliğinin aidiyeti üzerine sosyolojik bir araştırma, Konya.

[3] Atalay, A. (2012). Bireylerin sosyal alg1 ve sosyalleşme düzeylerinin gelişiminde rekreasyonel uygulamaların önemi. I. Rekreasyon Araştırmaları Kongresi Bildiri Kitabı, 12-15 Nisan, 958-970.

[4] Bucher, C.A., Bucher, R.D. (1974). Recreation for Today's Society, New Jersey: Prentice-Hall.

[5] Ertürk, Y.D. (2010). Davranış Bilimleri, İstanbul: Kutup Yıldızı Yayınları.

[6] Filiz, Z. (2010). Üniversite öğrencilerinin sosyalleşmesinde spora katılımın değerlendirilmesi, Niğde Üniversitesi Beden Eğitimi ve Spor Bilimleri Dergisi, 4(3), 192-203.

[7] Goodenow, C., Grady, K.E. (1993). The relationship of school belonging and friends' values to academic motivation among urban adolescent students, The Journal of Experimental Education, 62(1), 60-71.

[8] Karatzias, A., Power, K., Swanson, V. (2001). Quality of School Life: development and preliminary standardization of an instrument based on performance indicators in Scottish secondary schools. School Effectiveness and School Improvement, 12(3), 265-284.

[9] Kusat, A. (2003). Bir değerler sistemi olarak "kimlik" duygusu ve Atatürk, Erciyes Üniversitesi Sosyal Bilimler Enstitüsü Dergisi, 2(15), 45-61.

[10] Malone, G.P., Pillow, D.R., Osman, A. (2012). The general belongingness scale (gbs): assessing achieved belongingness, Personality and Individual Differences, 52, 311-316.

[11] Osterman, F.K. (2000). Students' need for belonging in the school community. Review of Educational Research, 70(3), 323-367.

[12] Öz, A. (2014). İlahiyat fakültesi öğrencilerinin kurumsal aidiyet düzeyi (aibü ilahiyat fakültesi örneği). $A \dot{I} B \ddot{U}$ Ilahiyat Fakültesi Dergisi, 2 (2), 54-64.

[13] Sarı, M. (2013). Lise öğrencilerinde okula aidiyet duygusu. Anadolu Üniversitesi Sosyal Bilimler Dergisi, 147-160.

[14] Şahan, H. (2008). Üniversite öğrencilerinin sosyalleşme sürecinde spor aktivitelerinin rolü. KMU İIBF Dergisi, 10 (15), 260-278. 